\title{
ANALISIS LIKUIDITAS, SOLVABILITAS DAN NILAI PASAR DAN PENGARUHNYA TERHADAP RETURN SAHAM PADA PERUSAHAAN SEKTOR PERBANKAN DI INDONESIA
}

\author{
Rizka Hadya \\ Program Studi Manajemen, Universitas Ekasakti \\ rizkahadya@gmail.com
}

\begin{abstract}
This study aims to determine the effect of Cash Ratio, Debt to Equity Ratio (DER) and the Price to Book Value (PBV) on stock returns banking companies listed in Indonesia Stock Exchange (IDX) period 2014-2017. The samples used were 23 banking companies listed in Indonesia Stock Exchange (IDX). In this study using two variables: the independent variable (Cash ratio, Debt to Equity Ratio and Price to Book Value) while the dependent variable is the stock return. The method used in this study is a multiple linear regression analysis using Eviews.

The results showed a partial (1) Liquidity Ratio (Cash Ratio) had no significant effect on stock returns, it is shown on the significance level of X1 (Cash Ratio) of 0.7105 $>$ 0.05. (2) Solvency Ratio (Debt to Equity Ratio) had no significant effect on stock returns, it is shown on the significance level of X2 (DER) of $0.9330>0.05$. (3) Market Ratio (Price to Book Value) has a significant effect on stock returns, it is shown on the significance level of X3 (PBV) of $0.0112<0.05$.

Keywords : liquidity (Cash Ratio), solvency (Debt to Equity Ratio (DER)), Market

Ratio(Price to Book Value (PBV)), stock returns

\section{PENDAHULUAN}

Sektor perbankan memegang peranan penting dalam kemajuan perekonomian Indonesia. Di Indonesia Perbankan merupakan salah satu sektor yang memiliki kekuatan finansial bagi perekonomian. Salah satu sektor pendukung kelangsungan berdirinya suatu perusahaah (bank) adalah ketersediaan dana. Sumber dana tersebut dapat diperoleh dengan menjual saham kepada masayarakat (public) di pasar modal. Menurut Husnan (2003), pasar modal adalah pasar untuk berbagai instrumen keuangan jangka panjang yang bisa di perjualbelikan, baik dalam bentuk hutang maupun modal sendiri.Lembaga

perbankan menawarkan kepada investor bahwa tingkat imbal hasil (return) yang akan diterimanya akan lebih cepat didapatkan.

Return merupakan hasil yang diperoleh dari investasi. Bagi investor, tingkat return ini menjadi faktor utama karena return adalah hasil yang diperoleh dari suatu investasi. Salah satu jenis investasi sekuritas yang paling popular di pasar modal adalah sekuritas saham. Saham adalah surat bukti kepemilikan persahaan (Sutrisno 2003:111). Laporan keuangan merupakan sebuah informasi yang penting bagi investor dalam mengambil keputusan investasi. Rasio keuangan digunakan untuk membandingkan
\end{abstract}


risiko dan tingkat imbal hasil dari berbagai perusahaan untuk membantu investor dan kreditor membuat keputusan investasi dan kredit yang baik (White et al, 2002).

Dalam penelitian ini ada tiga rasio yang digunakan untuk mengukur kinerja keuangan perusahaan yaitu likuiditas, solvabilitas dan rasio nilai pasar. Rasio likuiditas artinya bagaimana kemampuan perusahaan untuk melunasi kewajiban jangka pendeknya, yaitu dilihat dari perbandingan antara kewajiban lancar dan aktiva lancar, (Lukviarman,2006). Sebuah perusahaan yang dikatakan likuid apabila perusahaan mampu membayar semua kewajiban jangka pendeknya dengan aktiva lancar yang dimilikinya. Rasio solvabilitas adalah rasio yang menggambarkan kemampuan perusahaan dalam membayar kewajiban jangka panjangnya/kewajiban-kewajibannya apabila perusahaan dilikuidasi (Syafri,2008). Suatu perusahaan yang solvable berarti bahwa perusahaan tersebut mempunyai aktiva atau kekayaan yang cukup untuk membayar semua hutang-hutangnya begitu pula sebaliknya perusahaan yang tidak mempunyai kekayaan yang cukup untuk membayar hutang-hutangnya disebut perusahaan yang insolvable. Dan rasio nilai pasar yaitu rasio yang memberikan petunjuk mengenai apa yang dipikirkan investor atas kinerja

\section{Tabel 1}

Rata-rata CR, DER, PBV, dan Return Saham Pada Perusahaan Sektor Perbankan yang terdaftar di BEI

(Periode 2014-2017)

\begin{tabular}{|l|c|c|c|c|}
\hline Rata-rata & $\mathbf{2 0 1 4}$ & $\mathbf{2 0 1 5}$ & $\mathbf{2 0 1 6}$ & $\mathbf{2 0 1 7}$ \\
\hline Cash Ratio (\%) & 1,71 & 1,66 & 1,83 & 1,69 \\
\hline DER $(\mathbf{\%})$ & 8,62 & 8,05 & 7,96 & 7,69 \\
\hline
\end{tabular}

perusahaan dimasa lalu serta prospek dimasa mendatang (Moeljadi, 2006).

Kinerja keuangan dilakukan untuk mengetahui seberapa efektif manajemen dalam mengelola kinerja keuangan perusahaan serta memprediksi apakah perusahaan dapat kesejahteraan bagi investor. Untuk memperoleh return yang tinggi, seorang investor harus dapat menganalisis laporan keuangan perusahaan dengan baik sehingga memudahkan dalam pengambilan keputusan. Dari laporan keuangan tersebut diperoleh informasi tentang kinerja keuangan suatu perusahaan. Semakin baik kinerja keuangan suatu perusahaan akan semakin tinggi tingkat ekspektasi investor terhadap nilai suatu emiten dan menyebabkan semakin tinggi pula harga sahamnya. Meningkatnya harga saham akan membentuk return saham yang positif bagi investor. Sebaliknya semakin menurun kinerja keuangan akan menyebabkan penurunan harga saham dan membentuk return saham negatif bagi investor. Mengingat pentingnya return saham bagi para investor untuk menentukan apakah investor akan berinvestasi pada perusahaan tersebut atau tidak dapat dilihat dari tabel 1 dibawah ini : 


\begin{tabular}{|l|c|c|c|c|}
\hline $\boldsymbol{P B V}$ (x) & 1,90 & 1,95 & 1,57 & 1,62 \\
\hline Return Saham (\%) & 6,69 & 19,35 & $-9,24$ & 1,56 \\
\hline
\end{tabular}

Sumber:www.idx.com (Data Olahan)

Berdasarkan Tabel 1 terlihat bahwa cash ratio pada tahun 2014 sebesar 1,71 persen ini berarti perusahaan mampu memenuhi setiap 1 Rp hutang lancar di tutupi dengan 1,71 persen kas yang dimiliki perusahaan. Namun pada tahun 2015 rata-rata cash ratio mengalami penurunan sebesar 0,5 persen. Pada tahun 2016 cash ratio mengalami peningkatan yang drastis sebesar 1,83 persen bepengaruh negatif terhadap kemampuan memperoleh laba sehingga dapat di lihat bahwa Return saham berada pada nilai terendah -9,24 persen. Menurut hasil penelitian yang dilakukan Astiti,dkk (2013) menyatakan bahwa cash ratio tidak mempunyai pengaruh yang signifikan terhadap return saham.

Debt to equity ratio pada tahun 2014 DER sebesar 8,62 kali, ini menunjukkan bahwa semakin tinggi rasio ini menggambarkan gejala kurang baik bagi perusahaan. Pada tahun 2012 dimana penurunan DER pada nilai 8,05 persen diikuti dengan peningkatan Return saham ditahun yang sama pada angka 19,35 persen. semakin rendah rasio hutang modal maka semakin baik dan untuk keamana pihak luar rasio terbaik jika jumlah modal lebih besar dari jumlah hutang atau minimal sama, (syafri, 2008). Menurut hasil penelitian yang dilakukan Akbar (2013) menyatakan bahwa debt to equity ratio berpengaruh positif dan signifikan terhadap return saham. Hal ini bertentangan dengan penelitian yang dilakukan Faizal (2014) bahwa debt to equity ratio tidak berpengaruh signifikan terhadap return saham.
Semakin tinggi nilai PBV, semakin besar tambahan kekayaan yang dinikmati oleh pemilik perusahaan (Husnan, 2006). Dari tabel di atas hanya tahun 2014 hasil PBV yang tidak konsisten, dimana nilai PBV ynag tinggi sebesar 1,62 kali tidak diikuti denga Return saham yang tinggi pula yaitu sebesar 1,56 persen. Namun pada tahun 2012 nilai PBV yang tinggi yaitu 1,95 diikuti Return saham yang tinggi yaitu sebesar 19,35 persen. Menurut hasil penelitian yang dilakukan faizal (2014) menyatakan price to book value berpengaruh positif dan signifikan terhadap return saham. Berbeda dengan penelitan yang dilakukan Asbi (2008) bahwa PBV berpengaruh negatif dan signifikan terhadap return saham.

Dalam penelitian ini objek penelitian yang diambil adalah sektor Perbankan yang terdaftar di Bursa Efek Indonesia. Penelitian sebelumnya banyak yang meneliti tentang perusahaan manufaktur, industry dan sektor pertanian. Namun berbeda dengan penelitian ini, karena mengambil objek tentang sektor Perbankan. Periode yang akan diamati dalam penelitian ini yaitu 2014 hingga 2017.

\section{Pengaruh likuiditas terhadap Return saham}

Return Saham adalah hasil atau keuntungan dari suatu investasi berbentuk saham yang diperoleh dari selisih kenaikan (capital gains) dan selisih penurunan (capital loss) (Tandelilin, 2001). Likuiditas adalah 
mengukur kemampuan perusahaan memenuhi kewajiban jangka pendeknya, (Lukviarman, 2006). Rasio ini diukur menggunakan cash ratio yaitu perbandingan antara kas dengan hutang lancar (Kasmir, 2013).

Penelitian yang dilakukan Akbar (2013), pada perusahaan sektor Pertanian dengan periode pengamatan selama 4 tahun, yaitu 2008 hingga 2011. Teknik sampel yang digunakan adalah purposive sampling. Berdasarkan kriteria yang ditetapkan diperoleh jumlah sampel sebanyak 13 perusahaan sektor Pertanian yang terdaftar di Bursa Efek Indonesia. Hasil penelitiannya menyebutkan bahwa likuiditas mempunyai pengaruh yang positif signifikan terhadap return.

Sama dengan hasil penelitian yang dilakukan faizal (2014), pada perusahaan Manufaktur dengan periode pengamatan selama 3 tahun, yaitu 2010 hingga 2012. Teknik analisis yang digunakan adalah analisis regresi linear berganda, yang menunjukkan secara parsial bahwa likuiditas berpengaruh positif dan signifikan terhadap return saham. Namun berbeda dengan hasil penelitian Astiti,dkk (2014), pada sektor otomotif dan komponen yang terdaftar di Bursa Efek Indonesia. Dengan jumlah sampel sebanyak 10 perusahaan Manufaktur, periode pengamatan selama 3 tahun yaitu 2010 hingga 2012. Hasil penelitiannya menunjukkan bahwa secara parsial likuiditas tidak mempunyai pengaruh yang signifikan terhadap return saham, hal tersebut ditunjukkan dari tingkat signifikansi X1 (Cash Ratio) sebesar $0,462>0,05$.

Berdasarkan penjelasan di atas, dapat dikembangkan hipotesis pertama yaitu : Likuiditas berpengaruh positif terhadap return saham pada perusahaan sektor perbankan yang terdaftar di Bursa Efek Indonesia.

\section{Pengaruh solvabilitas terhadap Return Saham}

Rasio solvabilitas merupakan rasio yang menggambarkan kemampuan perusahaan dalam membayar kewajiban jangka panjangnya/kewajiban-kewajibannya apabila perusahaan dilikuidasi, (Syafri, 2008). Rasio solvabilitas diukur menggunakan Debt to equity ratio, yaitu dengan membandingkan total hutang (hutang lancar dan hutang jangka panjang) dengan total modal sendiri, (Lukviarman, 2006).

Penelitian yang dilakukan Akbar (2013), pada perusahaan sektor Pertanian yang terdaftar di Bursa Efek Indonesia. Periode pengamatan penelitian yang dilakukan selama 4 tahun, yaitu 2008 hingga 2011. Hasil penelitiannya menyebutkan bahwa solvabilitas mempunyai pengaruh yang positif dan signifikan terhadap return saham. Diamana dalam penelitian tersebut menggunakan dua variabel yaitu variabel bebas (Current ratio, debt to equity ratio dan price to book value) dan variabel terikat return saham.

Sama dengan hasil penelitian yang dilakukan Arsiti, dkk (2014), juga mengatakan bahwa solvabilitas mempunyai pengaruh yang positif dan signifikan terhadap return saham pada perusahaan Otomotif dan Komponen yang terdaftar di Bursa Efek Indonesia. Teknik analisa pengambilan sampel yaitu dangan cara purposive sampling, diperoleh sampel sebanyak 10 perusahaan otomotif dan komponen yang terdaftar di Bursa Efek Indonesia. 
Namun berbeda dengan penelitian yang dilakukan Faizal (2014), yaitu Pengaruh rasio likuiditas, rasio profitabilitas, rasio Aktivitas, rasio solvabilitas, dan rasio nilai pasar Terhadap return saham yang terdaftar di Bursa Efek Indonesia. Periode pengamatan selama 3 tahun, yaitu 2010 hingga 2012. Hasil penelitian tersebut menyatakan bahwa solvabilitas tidak mempunyai pengaruh yang signifikan terhadap return saham pada perusahaan Manufaktur.

Berdasarkan teori dan penelitian di atas maka dapat dikembangkan hipotesis kedua yaitu : Solvabilitas berpengruh positif terhadap return saham pada perusahaan sektor perbankan yang terdaftar di Bursa Efek Indonesia.

\section{Pengaruh nilai pasar terhadap Return Saham}

Rasio nilai pasar adalah mengukur harga pasar saham perusahaan relatif terhadap nilai bukunya, (Hanafi, 2004). Rasio ini diukur menggunakan price to book value, semakin tinggi rasio ini, semakin besar tambahan kekayaan (wealth) yang dinikmati oleh pemilik perusahaan, (Husnan, 2006). Penelitian yang dilakukan Akbar (2013), pada perusahaan sektor pertanian yang terdaftar di Bursa Efek Indonesia periode 2008-2011. Dimana periode pengamatan yang dilakukan selama 4 tahun. Hasil penelitian tersebut menyatakan bahwa Rasio nilai pasar berpengaruh positif signifikan terhadap return saham.

Sama dengan hasil penelitian yang dilakukan Faizal (2014), bahwa Rasio nilai pasar berpengaruh positif dan signifikan terhadap return saham pada perusahaan Manufaktur, hasil tersebut dinuktikan dengan signifikasi t sebesar 3,264. Dimana sampel dalam penelitian ini sebanyak 37 perusahaan manufaktur yang terdaftar di Bursa Efek Indonesia. Berbeda dengan penelitan yang dilakukan Asbi (2008), tentang Analisis Faktor Fundamental dan Nilai Kapitalisasi Pasar Terhadap Return Saham Perusahaan Manufaktur di BEI periode 2002-2006. Dengan variabel yang digunakan adalah price to book value, debt to equity ratio, return on assets, net profit margin dan variabel kapitalisasi pasar menunjukkan hasil bahwa PBV berpengaruh negatif dan signifikan terhadap return saham.

Dari teori dan penelitian terdahulu dikembangkan hipotesis ketiga yaitu : Rasio nilai pasar berpengaruh positif terhadap return saham pada perusahaan sektor perbankan yang terdaftar di Bursa Efek Indonesia.

\section{METODE PENELITIAN}

Jenis Penelitian ini adalah bersifat Kuantitatif. Data yang digunakan dalam penelitian ini adalah data sekunder yaitu seluruh perusahaan perbankan yang terdaftar di Bursa Efek Indonesia periode 2014-2017.

Jumlah Populasi dari penelitian ini adalah seluruh perusahaan sektor perbankan yaitu sebnayak 37 perusahaan sektor perbankan yang terdaftar di BEI periode 2014 hingga periode 2017. Pengambilan sampel dilakukan dengan metode purposive sampling dengan tujuan untuk mendapatkan sampel yang representatif. Purposive sampling adalah teknik pengambilan sampel sumber data dengan pertimbangan tertentu, Sugiyono (2010:218). Kriteria yang digunakan dalam penentuan sampel penelitian adalah : (a) 
Perusahaan termasuk dalam sektor perbankan selama periode 2014-2017.

(b) Perusahaan terus listing di Bursa Efek Indonesia selama periode 20142017. (c). Menerbitkan laporan keuangan selama periode 2014-2017 (d). Perusahaan tercatat mempunyai daftar harga saham (closing price) selama tahun 2014-2017.
Jumlah sampel yang memenuhi kriteria dalam penelitian ini adalah 23 besar perusahaan perbankan yang terdaftar di BEI pada periode 20142017. Dari hasil pooling yang tersedia maka jumlah data observasi adalah 92 buah yang diperoleh dari jumlah bank yang masuk dalam kriteria yaitu sebanyak 23 dikalikan dengan periode penelitian yaitu selama empat tahun.

Tabel 2

Defenisi Variabel

\begin{tabular}{|l|l|l|l|}
\hline No & Variabel & \multicolumn{1}{|c|}{ Defenisi } & Pengukuran \\
\hline 1 & Return Saham & $\begin{array}{l}\text { Perbandingan harga } \\
\text { saat ini dan harga } \\
\text { sebelumnya dengan } \\
\text { harga sebelumnya } \\
\text { (Brigham dan Houston, } \\
\text { 2006). }\end{array}$ & Return Saham $=\frac{(P 1-P 0)}{P 0}$ \\
\hline 2 & Likuiditas & $\begin{array}{l}\text { Kemampuan kas yang } \\
\text { dimiliki perusahaan } \\
\text { dalam memenuhi } \\
\text { kewajiban lancar tahun } \\
\text { bersangkutan (Kasmir, } \\
\text { 2013). }\end{array}$ & Cash $R=\frac{\text { Kas }}{\text { Hutang Lancar }}$ \\
\hline 3 & Solvabilitas & $\begin{array}{l}\text { Perbandingan antara } \\
\text { total hutang dengan } \\
\text { modal sendiri } \\
\text { (Lukviarman,2006). }\end{array}$ & DER = Total Hutang \\
\hline 4 & Rasio pasar & $\begin{array}{l}\text { Berapa besar nilai } \\
\text { perusahaan dari apa } \\
\text { yang telah atau sedang } \\
\text { ditanamkan oleh } \\
\text { pemilik perusahaan } \\
\text { (Husnan, 2006) }\end{array}$ & BV per share \\
common equity
\end{tabular}

Sumber : (data diolah)

Langkah selanjutnya adalah melakukan pengolahan data dengan menggunakan analisis regresi berganda (multiple regresision). Penelitian ini menggunakan program Eviews untuk memperoleh semua nilai yang 
diinginkan pada model analisis regresi dan pengujian secara statistik. Sebelum uji regresi dilakukan terutama yang dilakukan adalah uji stasionaritas, yaitu untuk mengetahui apakah data stasioner atau tidak diketahui dari nilai probability $<0,05$. Selanjutnya uji asumsi klasik digunakan untuk mendapatkan penduga koefisien regresi yang mempunyai error terkecil atau model regresi yang dihasilkan adalah sifat BLUE (Best Linier Unbiased Estimed). Adapun uji asumsi klasik yaitu : (a) Normalitas data adalah untuk melihat data terdistribusi normal atau tidak yaitu dilihat dari nilai Probability Jarque-Bera $>$ tingkat alpha $5 \%$. (b). Multikolenieritas adalah jika nilai korelasi antar variabel independen <
0,8 maka tidak terjadi multikolinearitas. Jika nilai korelasi > 0,8 maka terjadi multikolinearitas. (c). Otokorelasi yaitu untuk melihat ada tidaknya otokorelasi, jika DurbinWastonnya antara -2 sampai 2 berarti tidak terjadi otokorelasi. (d).Heterokedastisitas untuk melihat apakah model regresi terjadi kesamaan variance dari residual suatu pengamatan ke pengamatan lain (Ghozali, 2005). Analisis regresi linier berganda digunakan untuk menganalisis hipotesis dalam penelitian ini dengan tingkat signifikasi yang digunakan sebesar $5 \%$. Model analisis linier berganda dapat dirumuskan sebagai berikut :

Return Saham $=\alpha+\beta_{1}$ Cash Ratio $+\beta_{2} \mathrm{DER}+\beta_{3} \mathrm{PBV}+\varepsilon$

Dimana : Return Saham = Variabel Dependen

$\alpha=$ konstanta

$\beta_{1}, \beta_{2}, \beta_{3}=$ koefisien variabel cash ratio,DER, PBV

Cash ratio, DER dan PBV $=$ Variabel Independen

$\varepsilon=$ Kesalahan random

HASIL DAN PEMBHASAN

Obyek penelitian yang digunakan dalam penelitian ini adalah seluruh perusahaan perbankan yang terdaftar di BEI selama periode 2014 hingga 2017. Populasi perusahaan perbankan yang terdaftar di BEI pada periode tersebut berjumlah 37 perusahaan. Pengambilan sampel dalam penelitian ini dilakukan dengan purposive sampling yaitu pengambilan sampel berdasarkan kriteria tertentu. Berdasarkan kriteria tersebut sampel yang bisa digunakan (memenuhi kriteria) adalah 23 perusahaan perbankan yang tercatat di BEI. Terdapat 14 perusahaan yang gugur yaitu karna tidak memenuhi kriteria yang telah ditetapkan dan tidak ada kelengkapan data anatar lain : (1) ada dua perusahaan delisting dari BEI, (2) ada enam perusahaan yang tidak menerbitkan laporan keuangan pada periode 2014 dan 2015, (3) ada enam perusahaan tidak mempunyai nilai return saham. 


\section{Analisis Linear Berganda}

Tabel 3

Hasil Uji Regresi Linear Berganda

\begin{tabular}{lrlll} 
Variable & Coefficient & Std. Error & t-Statistic & Prob. \\
\hline \hline \multicolumn{1}{c}{ C } & 0.786736 & 0.162983 & 4.827112 & 0.0000 \\
CASH & 1.149404 & 3.086725 & 0.372370 & 0.7105 \\
DER & -0.001074 & 0.012731 & -0.084359 & 0.9330 \\
PBV & 0.580113 & 0.223931 & 2.590593 & 0.0112 \\
\hline \hline R-squared & 0.073285 & Mean dependent var & 1.038478 \\
Adjusted R-squared & 0.041692 & S.D. dependent var & 0.287929 \\
S.E. of regression & 0.281863 & Akaike info criterion & 0.347713 \\
Sum squared resid & 6.991314 & Schwarz criterion & 0.457356 \\
Log likelihood & -11.99482 & Hannan-Quinn criter. & 0.391966 \\
F-statistic & 2.319681 & Durbin-Watson stat & 2.409407 \\
Prob(F-statistic) & 0.080834 & & \\
\hline \hline
\end{tabular}

\section{Pembahasan}

\section{Pengaruh Cash Ratio terhadap Return Saham}

Dari Tabel 3 dihasilkan nilai $\alpha$ sebesar 0,7867 dan nilai $\beta$ untuk variabel likuiditas (cash ratio) sebesar 1,1494. Secara determinan $(R$ Squared), cash ratio mempengaruhi return saham sebesar 0,0026 dan selebihnya dipengaruhi oleh faktor lain. Pada tabel tersebut dihasilkan nilai koefisien regresi untuk variabel likuiditas (cash ratio) sebesar 1,1494 bertanda positif dengan nilai probabilitas $0,0710>0,05$ yang bearti bahwa Cash ratio mempunyai pengaruh positif tidak signifikan terhadap return saham. Dengan demikian dapat disimpulkan hipotesis pertama ditolak.

Hasil penelitian ini mendukung penelitian sebelumnya yang dilakukan astiti, dkk (2014) yang menunjukkan bahwa cash ratio tidak berpengaruh positif dan signifikan terhadap return saham pada perusahaan Otomotif dan Komponen periode 2010 hingga 2012.

\section{Pengaruh Debt to Equity Ratio terhadap Return Saham}

Dari Tabel 3 dihasilkan nilai $\alpha$ sebesar 0,7867 dan nilai $\beta$ untuk variabel solvabilitas (debt to equity ratio) sebesar -0,00107. Secara determinan ( $R$-Squared), debt to equity ratio mempengaruhi return saham sebesar 0,000074 dan selebihnya dipengaruhi oleh faktor lain. Dihasilkan nilai koefisien regresi untuk variabel DER sebesar $\quad-0,00107$ bertanda negatif dengan nilai probabilitas 0,9330 $>0,05$ yang bearti bahwa DER mempunyai pengaruh negatif tidak signifikan terhadap return saham. Dengan demikian dapat disimpulkan hipotesis kedua ditolak.

Hasil penelitian ini mendukung penelitian terdahulu yang dilakukan 
Faizal (2014), yang menunjukkan bahwa debt to equity ratio tidak berpengaruh signifikan terhadap return saham pada Manufaktur periode 2010 hingga 2012. Sama dengan hasil penelitian yang dilakukan Sabalno (2010) yang hasilnya menunjukkan bahwa debt to equity ratio tidak pengaruh signifikan terhadap return saham.

\section{Pengaruh Price to Book Value terhadap Return Saham}

Dari Tabel 3 dihasilkan nilai $\alpha$ sebesar 0,7867 dan nilai $\beta$ untuk variabel nilai pasar (price to book value) sebesar 0,5801. Secara determinan ( $R$-Squared), price to book value mempengaruhi return saham sebesar 0,07165 dan selebihnya dipengaruhi oleh faktor lain. Nilai koefisien regresi untuk variabel PBV sebesar 0,5801 bertanda positif dengan nilai probabilitas $0,0112<0,05$ yang bearti bahwa PBV mempunyai pengaruh positif yang signifikan terhadap return saham. Dengan demikian dapat disimpulkan hipotesis ketiga diterima.

Hasil penelitian ini mendukung penelitian terdahulu yang dilakukan oleh Faizal (2014), yang hasilnya menunjukkan bahwa price to book value memiliki pengaruh positif dan signifikan terhadap return saham pada perusahaan Manufaktur periode 2010 hingga 2012. Sama dengan hasil penelitian yang dilakukan Akbar (2013), bahwa price to book value berpengaruh signifikan terhadap return saham pada perusahaan sektor Pertanian periode 2008 hingga 2011.

\section{KESIMPULAN DAN SARAN Kesimpulan}

Berdasarkan hasil analisis data tentang pengaruh rasio likuiditas, rasio solvabilitas, dan rasio nilai pasar yang masing-masing diproksikan oleh cash ratio, debt to equity ratio, dan price to book value terhadap return saham perusahaan perbankan yang terdaftar di Bursa Efek Indonesia periode 20142015, dapat disimpulkan bahwa:

Rasio Likuiditas yang di proksikan oleh Cash Ratio (CR) berpengaruh positif dan tidak signifikan terhadap return saham. dihasilkan nilai koefisien regresi untuk variabel likuiditas (cash ratio) sebesar 1,1494 bertanda positif dengan nilai probabilitas 0,07105 > 0,05 yang bearti bahwa Cash ratio mempunyai pengaruh positif tidak signifikan terhadap return saham. Dapat disimpulkan hipotesis pertama ditolak.

Rasio Solvabilitas yang di proksikan oleh Debt to Equity Ratio (DER) berpengaruh positif dan signifikan terhadap return saham. Hal ini dibuktikan dengan nilai koefisien regresi untuk variabel DER sebesar 0,001074 bertanda negatif dengan nilai probabilitas $0,9330>0,05$ yang bearti bahwa DER mempunyai pengaruh negatif tidak signifikan terhadap return saham. Dengan demikian dapat disimpulkan hipotesis kedua ditolak.

Rasio Nilai Pasar yang di proksikan oleh Price to Book Value (PBV) berpengaruh positif dan signifikan terhadap return saham. dihasilkan nilai koefisien regresi untuk variabel PBV sebesar 0,580113 bertanda positif dengan nilai probabilitas $0,0112<0,05$ 
yang berarti bahwa PBV mempunyai pengaruh positif yang signifikan terhadap return saham Dengan demikian dapat disimpulkan hipotesis ketiga diterima.

\section{Saran}

Berdasarkan kesimpulan dan keterbatasan pada penelitian ini, maka dapat disampaikan beberapa saran sebagai berikut:

Bagi calon investor yang ingin berinvestasi pada saham, sebaikknya lebih mempertimbangkan faktor Cash ratio dan PBV karena faktor tersebut terbukti memiliki pengaruh yang signifikan terhadap return saham perusahaan perbankan yang terdaftar di Bursa Efek Indonesia periode 20142017.

Bagi peneliti dengan topik yang sejenis disarankan untuk melakukan kajian lebih lanjut dengan memasukkan variabel bebas lainya, seperti inflasi, tingkat suku bunga dan faktor-faktor eksternal.

Peneliti selanjutnya sebaiknya memperpanjang periode penelitian, sehingga akan diperoleh gambaran yang lebih jelas tentang kondisi pasar modal Indonesia.

\section{DAFTAR PUSTAKA}

Andriza, R., \& Yusra, I. (2019). Pengaruh kepemilikan manajerial dan kebijakan deviden terhadap kemakmuran Investor dan nilai perusahaan yang tercatat pada indeks LQ45. INA-Rxiv.

Angraini, I., \& Yusra, I. (2019). Pendekatan data panel terhadap return saham: studi empiris pada perusahaan LQ45. INA-Rxiv.

Astiti, ari.C, dkk, (2014), Pengaruh Kinerja Keuangan Perusahaan Terhadap

Return Saham (Studi Pada Perusahaan Otomotif Dan Komponen Di Bursa Efek Indonesia Tahun 2010-2012), e-Journal S1 Ak Universitas Pendidikan Ganesha.

Brigham, F Eugene dan Joel F Houston, (2010), Esential of Financial Management, Second edition, Cengage Learning Asia, Pte Ltd Singapore.

Danil, A., \& Yusra, I. (2019). Pengaruh kausal antara ukuran perusahaan, nilai buku dan likuiditas saham di Bursa Efek Indonesia. INA-Rxiv.

Hadya, R. (2013a). Pengaruh Harga dan Risiko Saham Terhadap Likuiditas Saham Pada Perusahaan-Perusahaan Yang Terdaftar Di Bursa Efek Indonesia. Jurnal KBP, 1(2), 208-231.

Hadya, R. (2013b). Pengaruh Harga dan Risiko Saham terhadap Likuiditas Saham Pada Perusahaan-Perusahaan Yang Terdaftar Di Bursa Efek Indonesia. Jurnal KBP, 1(2), 208-231. Retrieved from https://akbpstie.ac.id/cmsz/medias/file/9. rizka 
hadya.pdf

Hadya, R. (2014a). Analisis likuiditas, solvabilitas, nilai pasar dan return saham: studi empiris pada perusahaan sektor perbankan yang terdaftar di Bursa Efek Indonesia. Jurnal Riset Manajemen Dan Akuntansi, 3(1), 107-118.

Hanafi, D., \& Yusra, I. (2019). Tangibility, liquidity, growth opportunity, dan leverage: studi pada perusahaan terdaftar di Bursa Efek Indonesia. INA-Rxiv, (2001).

Harahap, Sofyan Syafri, (2006), Teori Akuntansi, Edisi Pertama, Cetakan Keempat, PT.Raja Grafindo Persada, Jakarta.

Husnan, S, dan Pudjiastuti, E, (2012), Dasar-Dasar Manajemen Keuangan, Cetakan Pertama, Edisi Keenam, UPP STIM YKPN, Yogyakarta.

Juanda, Bambang dan Junaidi, (2012), Ekonometrika Deret Waktu, Teori dan Aplikasi, IPB Press.

Kasmir, ( 2013), Analisis Laporan Keuangan, PT. Raja Grafindo Persada, Jakarta

Kurniawan, A., \& Yusra, I. (2019). Apakah profitabilitas dan nilai buku berdampak terhadap return saham?: studi empiris pada perusahaan LQ45. INA-Rxiv.

Moejaldi, (2006), Manajemen Keuangan Pendekatan Kuantitatif dan Kualitatif, BEFE, Yogyakarta.

Mulfita, A., \& Yusra, I. (2019). Analisis regresi data panel terhadap likuiditas saham di Indonesia. INA-Rxiv.

Putra, I., \& Yusra, I. (2019). Analisis likuiditas saham menggunakan regresi data panel. INA-Rxiv.

Samsul, Muhammad, (2006), Pasar Modal dan Manajemen Portofolio, Erlangga, Jakarta.

Sari, N. N., \& Yusra, I. (2018). Analisis Likuiditas, Leverage dan Kebijakan Dividen berdasarkan Siklus Hidup Perusahaan pada Saham LQ45. INA-Rxiv.

Sugiyono, (2010), Metode Penelitian Bisnis, Pendekatan Kuantitatif, Kualitatif Dan R \& D, CV. Alfabeta, Bandung.

Sartono, Agus, (2008), Manajemen Keuangan Teori dan Aplikasi, BPFE: Yogyakarta.

Tandelilin, Eduardus, (2001) Analisi Investasi dan Manajemen Portofolio, Cetakan Pertama, Edisi Pertama, BPFE : Yogyakarta. 
Yulianti, Y. D., \& Yusra, I. (2019). Pergerakan indeks harga saham gabungan sebagai dampak dari variabel makro. INA-Rxiv, 1-11.

Yusra, I. (2014). Analisis Return dan Likuiditas Saham Sebelum dan Sesudah Pengumuman Right Issue di Bursa Efek Indonesia. Jurnal Riset Manajemen Dan Akuntansi, 1(2), 150-163.

Yusra, I., Hadya, R., Begawati, N., \& Istiqomah, L. (2019). Panel data model estimation: the effect of managerial ownership, capital structure, and company size on corporate value Panel data model estimation : the effect of managerial ownership, capital structure, and company size on corporate value. Journal of Physics: Conference Series, 1175, 1-6. https://doi.org/10.1088/17426596/1175/1/012285 